\title{
EFFECTIVENESS OF ENTOMOPATHOGENICAL AND CHEMICAL AGENTS FOR CONTROLLING THE PINK STEM BORER Sesamia cretica LED. ON SUGARCANE BREEDING VARIETIES AND EVALUATED THEIR YIELD CHARACTERS AT EL-SABAHIA STATION, ALEXANDRIA, EGYPT. Abo El-Ftooh A. A. ${ }^{1}$; Sahar F. Tawfik ${ }^{2}$ and O.M. Badawy ${ }^{2}$ 1- Sugar Crops Research Department, Nubaryia , Sugar Crops Research Institute, Agriculture Research Center, Egypt \\ 2- Agriculture Research Station (Sabahia), Alexandria, Sugar Crops Research Institute, Agriculture Research Center, Egypt.
}

\begin{abstract}
The aim of this investigation was protection the sugarcane breeding varieties from infestation with the pink stem borer , S. cretica Led, at El-Sabahia Station , Alexandria . G 85-37variety (95 borers/100 plants) was more susceptible to infestation with the pink stem borer in two seasons. Moreover G85-39 was the most resistance to this borer (24 borers $/ 100$ plants) in the same seasons. There were significantly among varieties value as susceptibility to infestation by $\mathrm{S}$. cretica. The leaves weight of G85-37 variety was the highest recorded (1312 gm ) in weight leaves value in both seasons. On other hand, the Co214 (775gm )was the least one in same character. Stalks weight character was significantly lower among varieties in both seasons. The highest total soluble solid (T.S.S) value was appointed in $1^{\text {st }}$ season by G85-39 (20.67). While it was low by F153 (16.33)\&(16.17) in both season respectively. During the season 2006/2007, the evolution of 4 insecticides and 2bioinsects were done. In the third day the Dipel 2x (B. th. krustaki ) reduced the population of $S$. cretica by $19.33 \%$ in first period time (three leaves stage) and $16.67 \%$ in second period (Harvest time ). While reduction $\%$ was $0.0 \%$ by $B$. bassiana ( Bio fly) in both period. Lannate reduction percentage was more toxicity $(91 \%)$ than Carbaryl $(80.67 \%)$ in same period . In three leaves stage ( $1^{\text {st }}$ period test) the Profenofos was very effective at third day (92.33). Bio-insecticides were more toxic in last priod(21day) for test at two application periods In addition, Dipel $2 x^{\circledR}$ is more toxic than (Bio fly ${ }^{\circledR}$ ). Organophosphours insecticides increased the sugarcane yield character than another tested insecticides. IT could be concluded that all tested insecticides could be used against $S$. cretica .Using chemical insecticides gave fast reduction of then Bio-insecticides which are safety and less pollution than chemical insecticides.
\end{abstract}

\section{INTRODUCTION}

Sugarcane is the first crops for production sugar in Egypt .The requirement for sugar is increased but the production are not enough to cover the consumption. Therefore the gape between production and consumption was increased and needed to great efforts to diminish this gape. (El Taweel, et al.,2005) . The pink stem borer Sesamia cretica Led. is the first most significant insect pest of sugar cane field. larvae feed first on the leaf. This feeding may result in "dead heart," due to the death of the growing tip. As the larvae grow they move to the whorl or leaf sheath area and feed. When leaves emerge, the "shot hole" feeding signs in the leaves can be 
Abo El-Ftooh A. A. et al.

seen. Most of the mature larvae will bore into the stalks, feed, and finish development there( Leopold Center Progress Reports ,1993). The pink stem borer Sesamia cretica caused losses annually for sugarcane crops at upper Egypt . Presently, growers use chemical insecticides to suppress populations of this insect. But sometimes this approach does not provide adequate protection from this pest and because the $S$. cretica tunneling damage within the sugarcane stalk is usually recognized too late. Moreover, because chemical insecticides are not only expensive but its made big pollutions in the agriculture land. In recent year, much attention has been paid to use of Bacillus. thuringiensis and Beauveria bassiana against Spodoptrea littaralis (Klein et.al ., 1996 and Abed El-Halim,1997 and Hardman and Gaul 1990).

For protection the sugarcane breeding varieties from infestation with the pink stem borer , S. cretica Led, two experiments were applied. First one was done during 2004/2005 and 2005/2006 seasons to select the susceptible sugarcane breeding variety from ten varieties and measured their character. In the second experiment, 2 entomopathogenical fungus \& bacterium and 4 insecticides from different groups were evaluated at two different intervals (at 3 leaves stage and at 21 days before harvest) during 2006/2007 season. Also, another goal of this investigation was to make progress toward to development of a management and reduced pollutions in agriculture environment.

\section{MATERAILS AND METHODS}

The experimental work was carried out during 2004/2005 and 2005/2006 sugarcane growing seasons in El-Sabahia Agricultural Research Station, Alexandria Governorate . Two experiments were applied ,the first one was done to select one susceptible sugarcane variety from ten varieties during 2004/2005, 2005/2006 seasons. The second one was applied six insecticides from different groups at two intervals (at 3 leaves age and at 60 before harvest ( harvest stage))during 2006/2007 From the first one seasons sugarcane varieties were F153, G 85-37, GT54 -9, G74-9, G75-368, Gg84 47, G84 - 68 , G85-39.Co413, and Co214. Each varieties were planted in the first week of April 2004 (Spring planting). The experimental area was divided into 40 plots .Each plot measured 6x7meters was equaled 1/100 Fadden. Each varieties was replicated in four plots, received regular agricultural practices. The randomized complete block design was used. The bioinsecticides, Beauveria Bassiana(Bio-fly ${ }^{\circledR}$ ) Bacillus. thuringiensis krustaki (Dipel 2x ${ }^{\circledR}$ ) and chemical insecticides were tested during 2006/2007 season in six separate replicated experiments The application was done when three leaves stage make a circle and 60 days before the harvest stage because the emergence of eggs is after 3-8 days (El-Sherif , 1970). Newly hatching larva moves about for sometime and takes shelter in between the stem and the leaf-sheath and mines into the epidermal layers of the leaf-sheath. It penetrates into the shoot in the third instars by boring holes in the middle of the stalk (David et al. 1986). During this period, the larva is exposure to insecticides or bio-insecticides. For that reason , 3 days later, the randomly 
sampled were chosen 25 plants in two stage. The average numbers of the leaf feeding (L.F.) and dead heart (D.H.) due to the infestation with S. cretica, were accounted and consider as indicator to susceptible varieties to the pink stem borer S. cretica. The chemical insecticides were tested in the field to decrease the number of the stem borer $S$. cretica. The treatments were applied by spraying the calculated amount in 400 liter water/fed. using a hand pressure equipment (El-Aswad 2003) . The treatments were :-

First group (Bio- insecticides )consisted of :-

a- Bacillus. thuringiensis krustaki (Dipel $2 \mathrm{x}^{\circledR}$ ) W.P $.500 \mathrm{~g} / \mathrm{fed}$ each $\mathrm{mg}$ consisted of 32000 international unit (Spores)

b- Beauveria bassiana (Bio fly ${ }^{\circledR}$ ) E.C. $400 \mathrm{~cm} / \mathrm{fed}$.

Second group Carbamte and oximecarbamate insecticides:-

a- Carbaryl $85 \%$ W.P.(Sevein®) $600 \mathrm{Cm} / \mathrm{fed}$.

Chemical name :1-naphthalenol, methylcabamate

Molecular .Form: $\mathrm{C}_{12} \mathrm{H}_{11} \mathrm{NO}_{2}$

b-Methomyl 50\% W.P.(Lannate (B) $350 \mathrm{~g} / \mathrm{fed}$

Chemical name :Ethanomidothioicacide, $\mathrm{N}$-(methylamino)carbonyloxylmethylester

Molecular Form: $\mathrm{C}_{5} \mathrm{H}_{10} \mathrm{~N}_{2} \mathrm{O}_{2} \mathrm{~S}$.

Third group (Organophosphours insecticides): -

a- Profenofos $72 \%$ E.C (Curacron®) $750 \mathrm{Cm} / \mathrm{fed}$.

Chemical name: O-(4-bromo-2 chloropheny) O-ethyl 5 propyl phosphorothioate.

Molecular Form: $\mathrm{C}_{11} \mathrm{H}_{15} \mathrm{BrClO}_{3} \mathrm{Ps}$

b)Chlorpyifos $48 \%$ E.C. (Dursban®) $1 \mathrm{~L} / \mathrm{fed}$.

Chemical name :O,O-dithyl O=(3,5,6-tirchloro-2-pyridinyl) phosphorothiote. Molecular .Form: $\mathrm{C}_{9} \mathrm{H}_{11} \mathrm{CL}_{3} \mathrm{NO}_{3} \mathrm{PS}$

The efficiency of treatments were based on the reduction in the stem borer S. cretica population according to the formula of Hinderson and Tilton (1955) .

The percentage of insects reduction $=1-\frac{T a^{*} C b}{T b^{*} C a} * 100$ where

$\mathrm{Ta}=$ The number of collected alive insects from the plot after the date of treatment.

$\mathrm{Tb}=$ The number of collected alive insects from the plot before the date of treatment.

$\mathrm{Ca}=$ The number of collected alive insects from the check plot after the date of treatment.

$\mathrm{Cb}=$ The number of collected alive insects from the check plot before the date of treatment.

The relative population densities of $S$. cretica were recorded for five intervals, i.e., 3,5, ,7,14 and 21 days

Increased percentage $=\frac{\text { Control }- \text { treatment }}{\text { Control }} * 100$

Statistical analysis was done according to Steel and Torrie (1981) 


\section{RESULTS AND DISCUSSION}

\section{1- Susceptibility of ten sugarcane breeding material to infest with $S$. cretica during 2004/2005 and 2005/2006seasons . \\ 1-1. Infestation with $S$. cretica.}

The aim of this investigation was to evaluate teen breading material ten sugarcane varieties towards susceptibility and some yield character at Agricultural Research Station (Sabahia), Alexandria region. The Assessment of susceptibility of sugarcane varieties to infestation by the pink stem borers $S$. cretica was recorded in Table (1) . This results showed that G85-37 variety was more susceptible to infestation to the pink stem borer in the first season (95 borers/100 plants) but G85-39 was more resistant to this borer (24 borer/plants) in the same season. These results were repeated in the second season which were (93.33 borers/100 plants) for G85-37 varieties was susceptible to infestation to the pink stem borer G85-39 variety was resistant to this borer (17.67 borer/plants) in the same seasons. In both seasons were highly significant among varieties as susceptibility to infestation by $S$. cretica. The varieties value as susceptibility of varieties to infestation by $S$. cretica can be put in descending arrangement in the first and second seasons as follow : G85-37 (95\& 93.33 borers /100 plant), GT54-9 (85.33\&82 borers/100 plant) ,G74-9(73.33\&73.33 borers/100 plant), F153 (54.33\&54.33 borers/100 plant) G84-/68 (48\&61 borers/100 plant), Co413 (41.33\&45 borers), G75-368 (36.\&23.67 borers)Co214 (35\&37 borers)Gg84-47 (30.67\&32.67 borers) and G85-39(24\&17.67 borers/100 plants).. Sensitivity in some varieties was differences and was less from first season than second one such as G85-37, GT 54-9, G75-36, and G8539.In contrarily, G84-/68, Co214, Co413 and Gg84-47 were higher . There were significance among varieties values as susceptibility to infestation by $S$. cretica and there was no significance between studied years The same trend for the tested varieties were recorded in the leaves feeding (I.f) and dead hart (d.h) symptoms by infested S. cretica . Where, G85-37and G85-39 were the highest and the least susceptible varieties to infested by $S$. cretica, respectively .This result agree with Maareg et .all. (1933) who found that GT 54-9 and G 74-96 was susceptible to infestation by Chilo agammon .

\section{1-.2.Sugarcne breeding materials characters.}

The leaves weight of G85-37 variety was the highest record $(1312 \mathrm{gm})$ in both seasons. On the other hand, the Co214 variety $(775 \mathrm{gm})$ was the least value in the same character. In addition, there was no significantly between the two seasons In regard stalks weight measurement Gt54-9 in second 'season recorded the highest values $(3220 \mathrm{gm} / \mathrm{plants})$ but in the first season was $2170 \mathrm{gm}$. On other hand, the stalks weight of G85-37 were 2420 \& $2680 \mathrm{gm}$ in first and second seasons, respectively. G85-39 was the least stalk weight in first season but Co214 (1.630gm) was the least stalk weight in $2^{\text {nd }}$ season. Significant value was low among varieties in this Stalk weight measurement in both seasons. The highest total soluble solid (T.S.S) value was appointed in $1^{\text {st }}$ season by G85-39 (20.67).While the lowest value was recorded by F153 (16.33)\&(16.17) in $2^{\text {nd }}$ season. These 
values had little significant difference in $1^{\text {st }}$ and $2^{\text {nd }}$ seasons. The highest sucrose $\%$ by G85-39 (15.92\%) in $1^{\text {st }}$ season but it was (15.8\%) by G74-9 variety. On the other hand the lowest values were( $12.57 \& 12.77 \%$ ) by F153 variety in two seasons respectively.

Table (1) :- Susceptibility of ten sugarcane breeding martial to infested with $S$. cretica during two successive seasons (2004/2005 and 2005/2006).

\begin{tabular}{|c|c|c|c|c|c|c|c|c|c|}
\hline \multirow{2}{*}{ Varieties } & \multicolumn{3}{|c|}{ No.borers/100plants } & \multicolumn{3}{|c|}{ 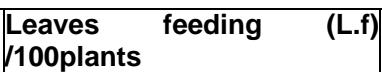 } & \multicolumn{3}{|c|}{$\begin{array}{c}\text { Deed hart (D.H) } \\
\text { /100plants }\end{array}$} \\
\hline & $\begin{array}{c}1^{\text {st }} \\
\text { season }\end{array}$ & \begin{tabular}{|c|}
$2^{\text {nd }}$ \\
season
\end{tabular} & Mean & $\begin{array}{c}1^{\text {st }} \\
\text { season }\end{array}$ & $\begin{array}{c}2^{\text {nd }} \\
\text { season }\end{array}$ & Mean & $\begin{array}{c}1^{\text {st }} \\
\text { season }\end{array}$ & \begin{tabular}{c|}
$2^{\text {nd }}$ \\
season
\end{tabular} & Mean \\
\hline G 85-37 & 95.00 & 93.33 & 94.17 & 67.33 & 74.00 & 70.67 & 56.00 & 59.33 & 57.67 \\
\hline GT 54-9 & 85.33 & 82.00 & 83.67 & 62.00 & 63.33 & 62.67 & 53.00 & 50.33 & 51.67 \\
\hline G74- 9 & 73.33 & 73.33 & 73.33 & 53.33 & 55.67 & 54.50 & 42.33 & 45.00 & 43.67 \\
\hline F 153 & 54.33 & 54.33 & 54.33 & 38.00 & 44.00 & 41.00 & 28.67 & 34.00 & 31.34 \\
\hline G84 - 68 & 48.00 & 61.00 & 54.50 & 32.67 & 46.67 & 39.67 & 26.67 & 36.33 & 31.50 \\
\hline Co 413 & 41.33 & 45.00 & 43.17 & 26.33 & 34.67 & 30.50 & 24.67 & 26.00 & 25.34 \\
\hline Gg84-47 & 36.00 & 23.67 & 29.83 & 25.33 & 24.33 & 24.83 & 20.33 & 12.33 & 16.33 \\
\hline Co214 & 35.00 & 37.00 & 36.00 & 26.67 & 27.00 & 26.84 & 23.00 & 21.00 & 22.00 \\
\hline Gg84-47 & 30.67 & 32.67 & 31.67 & 23.00 & 23.33 & 23.17 & 19.67 & 20.67 & 20.17 \\
\hline G85-39 & 24.00 & 17.67 & 20.83 & 15.67 & 15.00 & 15.34 & 15.33 & 12.00 & 13.67 \\
\hline L.S.D 0.5 & 5.51 & 4.51 & 3.55 & 2.246 & 3.267 & 2.313 & 2.833 & 2.933 & 2.158 \\
\hline
\end{tabular}

Table(2): Character of ten sugarcane varieties breeding materials under infested with S. cretica during two successive seasons .

\begin{tabular}{|c|c|c|c|c|c|c|c|c|c|c|c|c|}
\hline \multirow{3}{*}{ varieties } & \multicolumn{3}{|c|}{$\begin{array}{l}\text { Leaves weight } \\
\text { (gm)/plant }\end{array}$} & \multicolumn{3}{|c|}{$\begin{array}{l}\text { Stalks weight } \\
(\mathrm{gm}) / \text { plant }\end{array}$} & \multicolumn{3}{|c|}{ T.S.S\% } & \multicolumn{3}{|c|}{ Sucrose\% } \\
\hline & $1^{\text {st }}$ & $2^{\text {nd }}$ & Mean & $1^{\text {st }}$ & $2^{\text {nd }}$ & Mean & $1^{\text {st }}$ & $2^{\text {nd }}$ & & $1^{\text {st }}$ & & \\
\hline & & & & & & & & & & & & \\
\hline 37 & 1.32 & 1.31 & 1.312 & 2.42 & 2.68 & 2.817 & 19 & 18.67 & 18.8 & 14.63 & 14.75 & 14.7 \\
\hline & 03 & & 0.918 & 2.17 & & 2.3 & 18 & 19.33 & 19 & 13.86 & 27 & 14.57 \\
\hline & 03 & & 0.98 & 2.1 & 2.43 & 2.05 & 20.33 & 20 & 18.2 & 15.65 & & 15.73 \\
\hline & & & 0.79 & 1.89 & 2 & 2.045 & 16.33 & 16.17 & & 12.57 & & 12.67 \\
\hline G84 - 68 & 75 & & 0.778 & 1.75 & 2.2 & 1.925 & 18.33 & 17.67 & 18.3 & 14.11 & & 14.04 \\
\hline & 86 & & 0.898 & 2.03 & & 2.133 & 18 & 18.33 & & 3.86 & & 4.17 \\
\hline-47 & & & 0.85 & 2.1 & & 1.867 & 18 & 19 & & 13.86 & & 14.44 \\
\hline Co214 & 0.87 & & 0.775 & 2.27 & 1.63 & \begin{tabular}{|l|}
2.14 \\
\end{tabular} & 19.67 & 18.67 & 19 & 15.15 & & 14.95 \\
\hline & & & 0.795 & 1.82 & & 2.092 & 18.67 & 18. & & & & 14.43 \\
\hline & 0.71 & & 1.312 & 1.63 & 2.37 & 2 & 20.67 & 19.33 & 10.3 & 15.92 & & 15.59 \\
\hline L.S.D $\cdot 0.5$ & 0.12 & 0.167 & 0.101 & 0.192 & 0.309 & 0.175 & 1.71 & 2.09 & 1.2 & 2.388 & 2.388 & 1.711 \\
\hline
\end{tabular}

2. Efficacy of bio-insecticides on protection sugarcane G85-37 Varity during 2006 / 2007 season.

2-1.Infestation with $S$. cretica.

G85-37 variety was used as susceptible variety to the pink stem borer $S$. cretica to determine these pesticides against the pink stem borer Table (1). In Table (3) the microorganism group which employ two. biopesticides (B. th. krustaki and B. Bassiana).After the third day, the Dipel $2 x$ (B. th. krustaki ) the reduction \% number of S. cretica was $19.33 \%$ in first period time (three leaves stage ) and $16.67 \%$ reduction in the second period (Harvest stage) .These results agree with Mona El-Mandarawy et.al. (2005) 


\section{Abo El-Ftooh A. A. et al.}

who found that the population of S. cretica larvae decreased after spraying the combinations between $B$. th and chemical insecticide than the chemical insecticide alone followed by the bio-insecticide treatment.. On other hand , reduction \% at third day was $0.0 \%$ by $B$. Bassiana ( Bio fly) in both period. This results agree with Bruce et.al. (2000) who found that B. bassiana does not lose virulence towards the European corn borer, Ostrinia nubilalis (Hübner) B. bassiana. It could be explained the little effect of bio-insecticides because the emergence of eggs is after 3-8 days(El-Sherif,1970).Newly hatching larva moves about sometimes and takes shelter in between the stem and the leaf-sheath into the epidermal layers of the leaf-sheath. It penetrates into the shoot in the third instars by boring holes in the middle of stalk(David et.al,1986).During this period larva is exposed to insecticides .Also, bio-insecticides need more than day to appear their effect. An entomopathogenic fungus (B. bassiana) was possible for biological control, including the use of indigenous fungal inocula as insecticides. The reduction percentage increased slowly after the fifth day until the $21^{\text {th }}$ day by both bio-insecticides at first studied period. In the first period Dipel2x was much active $(64.12 \%)$ than Bio fly (39.3) the $5^{\text {th }}$ day when reduction was less in the $2^{\text {nd }}$ period $(42.33 \%)$ (Harvest time $) . B$. bassiana in the $5^{\text {th }}$ day gave approximately equal reduction in the two period. The seven day was $77.7 \%$ which increased until $96.33 \%$ in the $21^{\text {th }}$ day after application on the filed in the first period. While reduction percentage in second period was little active than same days by Dipel $2 x^{\circledR}$ (B. th. Krustaki) The B. Bassiana was recorded the same trend in both periods.

Generally, the first bio-insecticide achieved the higher reduction percentage in the end of the test $(96.33 \& 87.7)$ was preponderant on the fungus insecticides same end (93.6\&86.1\%) .

Second group, carbamate insecticides consists of Lannate \& Carbaryl. In the third day Lannate reduction percentage was early and more toxicity $(91 \%)$ than Sevein $(80.67 \%)$ in same day at $1^{\text {st }}$ period (three or more leaves). Lannate was less active in two subsequently days $(79.33 \%$ \& $80.33 \%)$ and then was increased in $14^{\text {th }}$ day and $21^{\text {th }}(91.33 \% \& 91.67 \%)$ respectively in the first period. In the harvest time (2nd period) Lannate toxicity took the same trend where, increased languid $80.33 \%$ until reached to $88.67 \%$ in twenty one day. Carbaryl $\left(\right.$ Sevein $\left.{ }^{\circledR}\right)$ pesticides in $21^{\text {st }}$ day was more toxicity (93.67\%) than Lannate in the same day $(91.33 \%)$.

Carbaryl effect was stopped at $5^{\text {th }}$ day $(83.33 \%)$ and $7^{\text {th }}(83.67 \%)$ and increased little in $14^{\text {th }}$ and in the end of test in first period (Three or more leaves). At harvest time Carbaryl $\left(\right.$ Sevein $\left.^{\circledR}\right)$ effective was improved from third day $(77 \%)$ until seven day then stopped at seven day to the end of test.

The organophorus insecticide group (Curacron \& Dursban) in three or more leaves the Curacron ${ }^{\circledR}$ were very active at third day (92.33), also Curacron was influential in general mean value than all pesticides under test application .These results agree with El-Aswad (2003) who reported that the synthetic insecticides Chlorpyifos had rapid effect at zero time . Curacron reduction were oscillated at intervals test subsequently:- $(92.33 \%, 84.00$, 92.67, 90.67 and $93.33 \%$ ). While, at harvest time the Curacron reduction 
values were increased changeless from third day (81.67\%) until twenty one day $(93.33 \%)$. The last insecticide in organophorus group was (Dursban ${ }^{\circledR}$ ) Profenofos reduction percentage were $(90.33$ \& $84.00 \%)$ in third day at three or more leaves and at harvest time, respectively. The Dursban toxicity increased until $21^{\text {st }}$ days after application period except in $5^{\text {th }}$ day was $76.61 \&$ 66.67 in two period .

Table (3): Reduction percentage of the pink stem borer S. cretica led under effect of bio- and chemical insecticides .

\begin{tabular}{|c|c|c|c|c|c|c|c|}
\hline \multirow[t]{2}{*}{ Period application } & \multirow[t]{2}{*}{ Insecticides } & \multicolumn{6}{|c|}{ Reduction \% } \\
\hline & & $\begin{array}{c}3 \\
\text { day }\end{array}$ & $\begin{array}{c}5 \\
\text { days }\end{array}$ & $\begin{array}{c}7 \\
\text { days }\end{array}$ & $\begin{array}{c}14 \\
\text { days }\end{array}$ & $\begin{array}{c}21 \\
\text { days }\end{array}$ & $\begin{array}{c}\text { General } \\
\text { means }\end{array}$ \\
\hline \multicolumn{8}{|c|}{ Microorganisms insecticides } \\
\hline Three leaves stage & \multirow{2}{*}{$\begin{array}{c}\text { B.th. } \\
\text { krustaki }\end{array}$} & 19.33 & 64.12 & 77.70 & 88.70 & 96.33 & 69.24 \\
\hline Harvest stage & & 16.67 & 42.33 & 53.70 & 85.30 & 87.70 & 57.14 \\
\hline Three leaves stage & \multirow[t]{2}{*}{ B .bassiana } & 0.00 & 39.30 & 79.70 & 84.70 & 93.60 & 59.46 \\
\hline Harvest stage & & 0.00 & 39.00 & 49.80 & 93.00 & 86.10 & 53.58 \\
\hline \multicolumn{8}{|c|}{ Carbamate insecticides } \\
\hline Three leaves stage & \multirow{2}{*}{ Lannate } & 91.00 & 79.67 & 80.33 & 91.33 & 91.67 & 86.80 \\
\hline Harvest stage & & 83.00 & 84.33 & 84.33 & 85.33 & 88.67 & 85.13 \\
\hline Three leaves stage & \multirow{2}{*}{ Carbaryl } & 80.67 & 83.33 & 83.67 & 93.33 & 93.67 & 86.96 \\
\hline Harvest stage & & 77.00 & 79.33 & 81.67 & 92.00 & 92.00 & 84.40 \\
\hline \multicolumn{8}{|c|}{ Organophorus insecticides } \\
\hline Three leaves stage & \multirow{2}{*}{ Chlorpyifos } & 92.33 & 84.00 & 92.67 & 90.67 & 93.33 & 90.60 \\
\hline Harvest stage & & 81.67 & 88.33 & 91.33 & 92.67 & 93.33 & 89.47 \\
\hline Three leaves stage & \multirow{2}{*}{ Profenofos } & 90.33 & 76.67 & 83.61 & 95.00 & 96.33 & 88.39 \\
\hline Harvest stage & & 84.00 & 66.67 & 80.33 & 94.67 & 89.67 & 83.07 \\
\hline
\end{tabular}

It can conclude from Table (3) that the bio-insecticides had higher effect in last day of the test at two studied period where Dipel $2 x^{\circledR}$ is more effect than (Bio fly $\left.{ }^{\circledR}\right)$ When want to use fast reduction then, used the chemical insecticides while the bio-insecticides was safety and less pollution than chemical insecticides.

As seen from Table (4) the leaves weight (gm) were higher values increased than control after application .Profenofos had superior effect in all tested sugarcane character. Dipel 2x ,Methomyl and Chlorpyifos had insignificantly different as on leaves weight than control. On other hand, (Bio fly ${ }^{\circledR}$ ) were caused the lot of increased than Dipel $2 x^{\circledR}$. All tested compounds were significantly increased than control except Dipel2x. The two organ phosphorous and Carbaryl gave the highest values of stalk. Contrary, the two bio-insecticides had a smaller effects than chemical insecticides. There were no significant for T.S.S. values. This findings reported here have important for protection sugarcane varieties breeding materials for infestation with $S$. cretica. Using chemical insecticides gave fast reduction of pest than bio-insecticides, which are safety and less pollution than chemical insecticides. 
Abo El-Ftooh A. A. et al.

Table (4): Effect of bio and chemical insecticides on sugarcane characters.

\begin{tabular}{|c|c|c|c|c|c|c|c|}
\hline \multicolumn{2}{|c|}{$\begin{array}{l}\text { Pesticides } \\
\text { Groups }\end{array}$} & $\begin{array}{c}\text { Leaves } \\
\text { weight } \\
(\mathrm{gm})\end{array}$ & $\begin{array}{c}\text { Increased } \\
\%\end{array}$ & $\begin{array}{c}\text { Stalk } \\
\text { weight } \\
(\mathrm{gm})\end{array}$ & $\begin{array}{c}\text { Increased } \\
\%\end{array}$ & $\begin{array}{c}\text { T.S.S } \\
\%\end{array}$ & $\begin{array}{c}\text { Increased } \\
\%\end{array}$ \\
\hline \multicolumn{2}{|c|}{\begin{tabular}{|l|l|} 
Microorganisms B.th. krusta \\
\end{tabular}} & 0.95 & 30.13 & 1.99 & 10.15 & 18 & -6.73 \\
\hline Insecticides & B .bassiana & 1.28 & 75.34 & 3.43 & 74.11 & 19 & -1.55 \\
\hline \multirow{2}{*}{$\begin{array}{c}\text { Carbamate } \\
\text { Insecticides }\end{array}$} & \begin{tabular}{|l|} 
Lannate \\
\end{tabular} & 0.85 & 16.44 & 2.73 & 38.58 & 19.3 & 0.00 \\
\hline & Carbaryl & 1.43 & 90.00 & 3.77 & 91.37 & 20 & 3.60 \\
\hline \multirow{2}{*}{$\begin{array}{l}\text { Organophorus } \\
\text { Insecticides }\end{array}$} & Chlorpyifos & 0.9 & 23.28 & 3.67 & 86.29 & 19 & -1.55 \\
\hline & Profenofos & 1.45 & 98.63 & 3.88 & 96.95 & 20.3 & 5.18 \\
\hline \multicolumn{2}{|c|}{ Control } & 0.73 & & 1.97 & & 19.3 & \\
\hline \multicolumn{2}{|c|}{ L.S.D 0.5} & & $333^{\star \star}$ & & $.139^{\star \star}$ & 2.292 & Ns \\
\hline
\end{tabular}

\section{REFERENCES}

Abed el-Halim, S.M.(1997). Efficacy and residual effect of some microbial and chemical insecticides against the cotton leaf warm Spodoptera litt oralis (Boisd) .Egyptian J. .of Biological pest control ,7(1):71-76.

Bruce L.; Wagner and Leslie C. Lewis(2000). Colonization of Corn, Zea mays, by the Entomopathogenic Fungus Beauveria bassiana. Applied and Environmental Microbiology, August 2000, p. 3468-3473, Vol. 66, No. 8.

David, H.; S. Easwaramoorthy and M. Jayanthi (1986). Sugarcane entomology in India . ed. By Sugarcane Breeding Institute, (Indian Council of Agricultural Research) Coimbatore- 641007, india 463 pp.

El-Aswad, A.F. (2003) Efficiency of four bio-insecticides and their combinations with Chlorpyifos as a new approach for integrated management of Spodoptera littoralis.J. of pest Envi.Sci.Vol.11.(1), April 2003.105-119.

El-Mandarawy, M.B.R.;S.A. Abdel Samae and M.A.Z. El-Naggar(2005). Efficacy of Bacillus thuringiensis alone or in combination with chemical insecticides on Sesamia cretica Led. and its associated natural enemies in maize field. Egypt. Egypt. J. Zool.(35):135-149.

El-Taweel ,F.M.A. A.A. Ouf and O.M. Badawy (2005).Effect of nitrogen fertilizer leavel and growing seasons on flowering , seed setting and some morphology and technological character of sugar cane varieties. International conference 1-6April 2005. Alexandria, Egypt.

El-Sherif, H.A.F.(1970).Studies on biology and control of the sugarcane stalk borers Sesamia. cretica led and Chilo agamemnon Biesin upper Egypt - Msc .thesis, Fac. of agric., Cairo .Egypt.

Hardman ,J.M. and S.O. Gaul (1990).Mixture of Bacillus. thuringiensis and pyrethroids control Winter Moth (Lepidoptra :Geometridea) in Orchards without causing outbreaks of mites. J. Econ. Entomol., 83(3) :920-936.

Hinderson, C.F. and Tilton, E.W.V. (1955) . Test with acaricides against the brown wheat mite. J. Econ. Ent., 48 : 187-191. 
Klein ,C . D . :D .R. Johoson ; H .B. Myers and L.M. Pagc (1996) .Evaluation of Bacillus. thuringiensis and ovicide combinations for bollwarm and tobacco budwarm Proc. Beltwide cotton conf.Nashville, TN, USA, 2:798-799.

Leopold Center Progress Report .(1993) Utilizing an entomopathogenic fungus, Beauveria bassiana, for season-long suppression of larval populations of the European corn borer. vol $2,12-88$.

Maareg ,M.F.; Abu-Dooh, AM.; and Ebieda, A.M.M. (1993). Varietal resistance to pink Lined Chilo agamemnon Bies and relative differential field loss of certain local sugarcane varieties in Egypt. Annals of Agric. Sc., Moshtohor. 31(1): 517- 526.

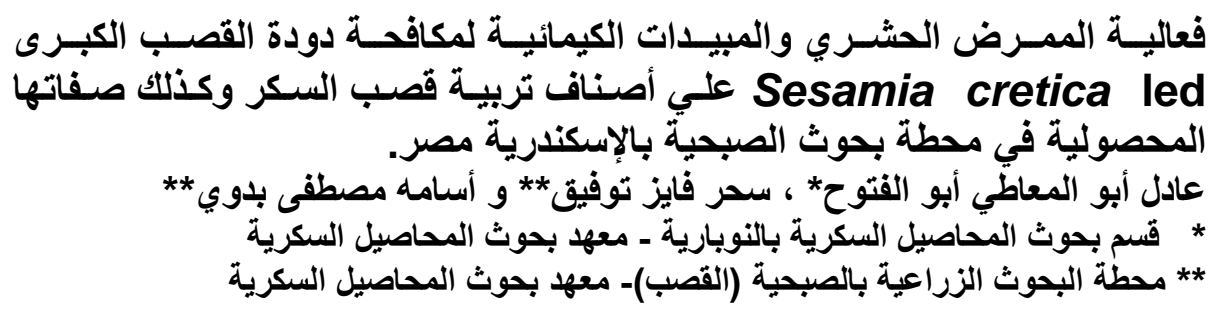

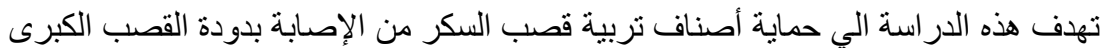

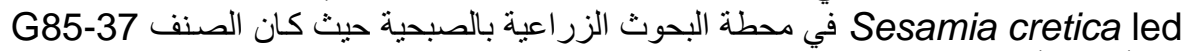

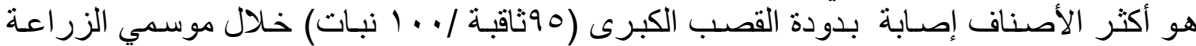

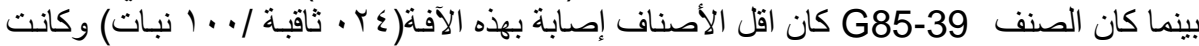

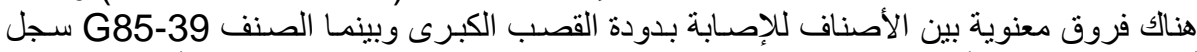

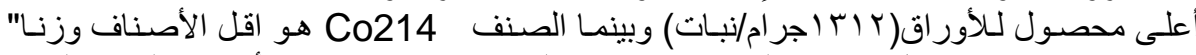

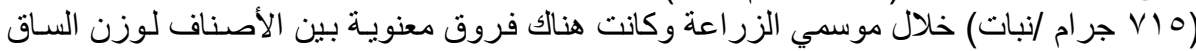

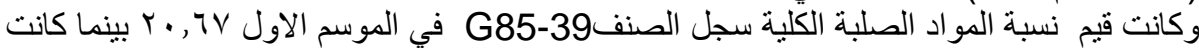

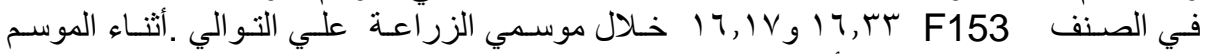

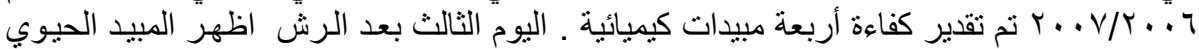

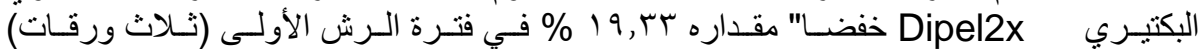

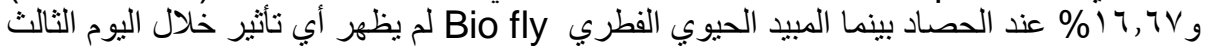

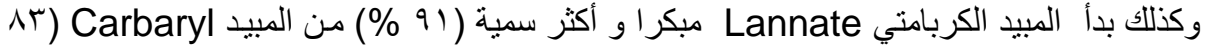
أظهر المبيد الفسفوري (Profenofos) أكثر سمية في اليوم الثالث (سب, ra) و كانت

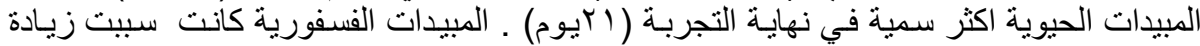

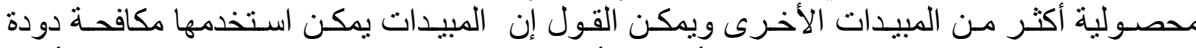

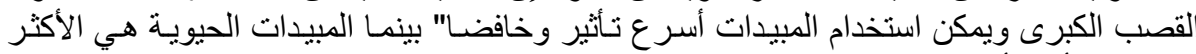

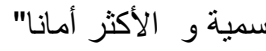

